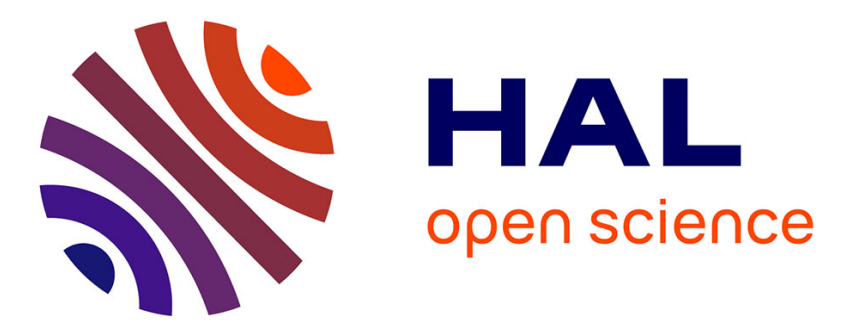

\title{
The inclusive leisure experience beyond the adapted or inclusive leisure dichotomy
}

Hélène Carbonneau, Adrienne Johnson, Frédéric Reichhart

\section{To cite this version:}

Hélène Carbonneau, Adrienne Johnson, Frédéric Reichhart. The inclusive leisure experience beyond the adapted or inclusive leisure dichotomy. Loisir et Société / Society and Leisure, 2021, 44 (2), pp.137-143. 10.1080/07053436.2021.1935425 . hal-03374128

\section{HAL Id: hal-03374128 \\ https://hal-inshea.archives-ouvertes.fr/hal-03374128}

Submitted on 7 Jan 2022

HAL is a multi-disciplinary open access archive for the deposit and dissemination of scientific research documents, whether they are published or not. The documents may come from teaching and research institutions in France or abroad, or from public or private research centers.
L'archive ouverte pluridisciplinaire HAL, est destinée au dépôt et à la diffusion de documents scientifiques de niveau recherche, publiés ou non, émanant des établissements d'enseignement et de recherche français ou étrangers, des laboratoires publics ou privés. 


\title{
The inclusive leisure experience beyond the adapted or inclusive leisure dichotomy
}

\author{
Hélène Carbonneau, Adrienne Johnson \& Frédéric Reichhart
}

To cite this article: Hélène Carbonneau, Adrienne Johnson \& Frédéric Reichhart (2021) The inclusive leisure experience beyond the adapted or inclusive leisure dichotomy, Loisir et Société / Society and Leisure, 44:2, 137-143, DOI: 10.1080/07053436.2021.1935425

To link to this article: https://doi.org/10.1080/07053436.2021.1935425

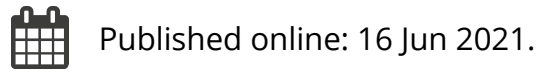

Submit your article to this journal $\sqsubset$

山 Article views: 46

Q View related articles ๘

View Crossmark data $₫$ 


\title{
INTRODUCTION
}

\section{The inclusive leisure experience beyond the adapted or inclusive leisure dichotomy}

\author{
Hélène Carbonneau ${ }^{\mathrm{a}}$, Adrienne Johnson ${ }^{\mathrm{b}}$ and Frédéric Reichhart ${ }^{\mathrm{c}}$
}

\begin{abstract}
${ }^{a}$ Département d'études en Loisir, Culture et Tourisme, Université du Québec à Trois-Rivières, Québec, Canada, ${ }^{b}$ Department of Health \& Human Physiology, Université d'Iowa, Iowa, IA, USA; ${ }^{c}$ Spécialité « conseiller en accessibilité » du master PIH A2, INS-HEA, Surennes, France
\end{abstract}

The areas of education and occupation have long been the focus of attention and collective mobilization, and have appeared in gold letters with regard to the demands of people with disabilities. We continue to wait for leisure activities to find their place between school and work, to find a legitimate but also recognized position. The right to leisure for people with disabilities has been slow to gain momentum and focus. Access to leisure takes the form of a diverse array of practical methods, organized both ideologically and practically between adapted and inclusive leisure activities. As written by Gilles Pronovost, "The field of leisure also constitutes an open door to the study of social change." He adds that: "social change generally implies both new modalities of social integration of all functional and structural elements, and an increase in the capacity of a society to adapt to its environment" (2017, p. 408, loose translation). In this sense, adapted and inclusive leisure activities resonate with the evolution of the social treatment of disabilities and also the place that society gives to people with disabilities.

In America, as well as in Europe, the emergence of adapted leisure appears first of all within specialized establishments in the sociomedical sector. Various artistic (painting, photography, pottery, etc.), cultural (museum outings, etc.), and physical and sporting (cycling, hiking, etc.) leisure activities are offered (Reichhart, 2007). Leisure practices are then often instrumentalized in order to optimize the functioning of people with disabilities. Leisure for the user becomes a means to an end that serves various purposes, mainly educational, therapeutic, or occupational. Moreover, the social and developmental importance of leisure for people with disabilities is also recognized, and access to leisure is provided for them (Reichhart, 2005). This access to leisure first emerges in the form of adapted offerings by organizations specializing in a categorical or differentiated approach. Commonly referred to as adapted leisure activities, they are based on a differentiated approach that advocates recognizing and taking into account the particularities of people with disabilities and consists of organizing specific leisure activities for this group. Designed and implemented on the basis of special needs, they can lead to stigmatization and segregation as a result of activities carried out on an individual basis, i.e., only among people with disabilities (Calvez, 1990).

It was not until the 1990s that the emergence and development of inclusive recreation became apparent. These so-called inclusive leisure activities give priority to welcoming and involving people with disabilities within the traditional or generalist leisure offerings. Activities that are only provided to users within the facility will gradually be

Corresponding author: Hélène Carbonneau Helene.Carbonneau@uqtr.ca Département d'études en Loisir, Culture et Tourisme, Université du Québec à Trois-Rivières, Québec, Canada 
transformed: activities will be relocated and practiced outside the facility (spatialization), will no longer be supervised by health and social services workers (internal-external supervision), and, above all, will be practiced with people who are not cared for by the facility and who are not disabled (socialization/mixed). Inclusive leisure would thus result from the evolution of leisure activities whose organization abolishes the boundary between inside and outside, internal and external, at the level of physical and social space (supervisors and practitioners). These activities embody a more normative modality which leads to a destigmatization by privileging unification. ${ }^{1}$ Based on assimilation, such activities defend the universality of humanity and the unity of the human race. Since the early 2000s, they have enjoyed political and social legitimacy under the aegis of inclusion. Inclusion is then seen as a way to enable people with disabilities to fully participate in society.

Traditionally, adapted leisure and inclusive leisure are perceived in opposition to each other, as incompatible, like two watertight silos. Instead, they should be recognized as a continuum of multidimensional offerings that guarantee full access to leisure. Beyond the form of the activity as such, it is important to consider the concept of inclusive experiences as it goes beyond this dichotomy of organizational methods and invites us to look more expansively at the experience of people with disabilities.

Several authors (including Pagán, 2015; Powrie et al., 2015) highlight the importance of giving people living with disabilities access to meaningful activities to enable them to enjoy a satisfying experience. Kang et al. (2014) as well as Carbonneau et al. (2015) identified three dimensions that influence this experience, namely physical access, social connection, and engagement in an activity. Beyond integration into a place or a group, it is therefore crucial to promote access to a satisfying experience that corresponds to people's interests and expectations. The inclusive leisure experience thus calls for providing access to places and facilities related to practices that are meaningful to people, allowing an experience that mobilizes people's potential in activities that respond to their interests and expectations, and optimizing the possibility of entering into meaningful and reciprocal relationships with other participants with and without disabilities (Carbonneau et al., 2015). This inclusive experience can take on a variety of forms, ranging from adaptive practice in specialized settings to inclusive practice in complete freedom, as illustrated in Figure 1.

It is important to emphasize here that this is not a continuum where adapted leisure in specialized settings would be the least attractive form of leisure, and inclusive leisure

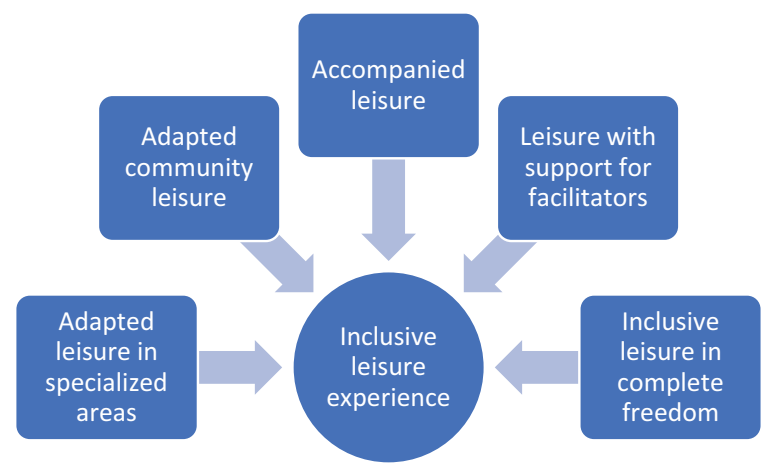

Figure 1. Range of possibilities for inclusive leisure experience (Carbonneau et al., 2015). 
would be the culmination of the leisure experience for a person with disabilities, but a range of possibilities. What is important is that the type of opportunity chosen is the most conducive to enabling participants to have a truly inclusive experience.

This notion of inclusive experience aligns with the concerns of many stakeholders, practitioners, and researchers in the field of leisure for people with disabilities. In October 2019, the first International Symposium on the Inclusive Leisure Experience was held in Trois-Rivières, bringing together researchers and stakeholders from Canada, the United States, France, Switzerland, Italy, and Spain. This special issue is a continuation of the symposium, which was rich in exchanges on the intricacies of supporting an inclusive leisure experience. You will find the reflections of leading researchers in this field as well as research results.

First, Kenneth Mobily and Adrienne Johnson's article frames the sense of belonging within the inclusive leisure experience. The authors then emphasize the experience of belonging and leisure as major forces in redefining disability and its meaning in contemporary society. The texts by Anne Marcellini and Mary Ann Devine expand the meaning and potential of inclusion in leisure for the development of society. Marcellini invites us to reflect on ways of going beyond the co-presence of people with and without disabilities and developing an inclusive society. Devine positions the notion of inclusive leisure within a social justice perspective. She emphasizes that leisure is more than a way to occupy time, it is a major vector of quality of life and even of the fight against oppression.

The following two articles introduce key conceptual models for the field of leisure inclusion from an ecological perspective. John Dattilo's article presents a model of inclusive education considering both the social and the physical environment. This model recognizes specific strategies for fostering engagement and inclusion. The purpose of this article and the model itself is to educate stakeholders in all areas of recreation about inclusion and the development of inclusive recreation services. Lynn Anderson discusses the relevance of the "Flourishing through Leisure" model to better understand how to support inclusive leisure practices in the community. This model is rooted in the concepts of the social model of disability, positive psychology, and the ecological perspective. Rodney Dieser's article adds an intercultural dimension to this analysis. This article highlights the significance of normalization theory as a basis for a multicultural approach to inclusive leisure from a comparative analysis of Nirje's and Wolfensberger's writings. Darla Fortune's text adds a reflection on the notion of belonging with relation to inclusion in leisure activities within the community. Fortune develops five themes highlighting ways to improve belonging, particularly for those at risk of exclusion.

Additional articles from Valérie Poulin and colleagues, and from Marie-Michèle Duquette and collaborators, bring forward additional examples of research within inclusive leisure experience. The following article by Poulin et al. presents the results of a study that explored the conditions for an inclusive leisure experience in creative workshops in libraries. This article illustrates that an inclusive leisure experience takes shape in three stages: before, during, and after the activity. The last article consists of a research note by Duquette et al. that highlights some of the issues involved in conducting a study on the issue of inclusive experience. It shows the importance of a close relationship with the practice environment from the conceptualization of the project, including the training of the actors, to its evaluation for optimal impact of the research on inclusion in recreation. 
We hope that reading the various texts contained in this special issue will contribute to a better understanding of inclusion in recreation and the importance of moving beyond the simple cohabitation of diverse audiences to support the achievement of an inclusive experience for all. Enjoy!

\section{L'expérience inclusive de loisir au-delà de la dichotomie loisir ségrégé et inclusif}

Les activités scolaires et professionnelles sont celles qui ont longtemps figuré en lettres d'or sur les bannières des revendications des personnes handicapées et autour desquelles se sont fortement concentrées l'attention et la mobilisation collective. Il faudra patienter pour que le loisir parvienne à se faufiler entre l'école et l'emploi, pour trouver une place légitime, mais également reconnue. C'est progressivement que le droit au loisir pour les personnes en situation de handicap va s'affirmer. Cet accès au loisir se concrétise par une diversité de modalités pratiques marquées tant idéologiquement que par leur mode d'organisation et finalités. Comme l'écrit Gilles Pronovost, « le champ du loisir constitue ainsi une porte ouverte à l'étude du changement social». Il ajoute que « le changement social suppose généralement à la fois de nouvelles modalités d'intégration sociale de l'ensemble des éléments fonctionnels et structurels, et une hausse de la capacité d'adaptation d'une société à son environnement »(2017, p. 408). En ce sens, les loisirs résonnent avec l'évolution du traitement social du handicap, mais aussi de la place que la société accorde aux personnes en situation de handicap.

Tant en Europe que sur le continent nord-américain l'émergence d'un loisir dit adapté apparait d'abord au sein des établissements spécialisés du secteur médico-social. Diverses pratiques de loisir artistique (peinture, photo, poterie, etc.), culturelle (sortie musée, etc.), physique et sportif (vélo, randonnée, etc.) sont proposées (Reichhart, 2007), souvent instrumentalisées afin d'optimiser le fonctionnement des personnes ayant des incapacités. Parfois, elles se prolongent lors de week-end ou de temps plus longs par des séjours de vacances ou camp d'été. Le loisir qui semble échapper à l'usager et au bénéficiaire devient un moyen qui répond à des finalités diverses pouvant être surtout éducatives, thérapeutiques ou occupationnelles. Par ailleurs, la portée sociale et d'épanouissement du loisir pour les personnes ayant des incapacités est aussi affirmée, même si dans ce cas, elle se concentre autour de pairs en situation de handicap ou d'intervenants sociaux (Reichhart, 2005). Ainsi l'accès au loisir se construit sous la forme d'une offre adaptée, façonnée par la prise en charge des organisations spécialisées dans une approche catégorielle. Communément désignées sous le terme de loisirs adaptés, ces activités se basent sur la différenciation : elles préconisent la reconnaissance et prise en compte des singularités des personnes handicapées et consistent en l'organisation d'activités de loisir spécifiques pour ce public. Pensées et mises en place à partir des besoins particuliers, elles peuvent entrainer une stigmatisation et ségrégation du fait d'activités pratiquées dans une logique d'entre soi, c'est-à-dire uniquement entre personnes handicapées (Calvez, 1990).

Il faudra attendre les années 1990 pour entrevoir l'émergence et le développement de loisirs inclusifs. Il s'agit alors de privilégier l'accueil et la participation de personnes handicapées au sein de l'offre classique ou généraliste de loisir. Certaines activités dispensées à des usagers au sein de l'établissement vont progressivement se transformer; certaines pratiques vont se délocaliser et se pratiquer en dehors de l'établissement (spatialisation), ne plus être encadrées par des intervenants en santé et services sociaux (encadrement interne-externe) et surtout être pratiquées avec des personnes non prises en 
charge par la structure et non handicapées (socialisation/mixité). Le loisir inclusif résulterait ainsi de l'évolution des activités de loisirs dont l'organisation abolit la frontière entre le dedans et le dehors, l'interne et l'externe au niveau de l'espace physique et social (encadrants et pratiquants). Il incarne une modalité d'accès au loisir plus normative qui conduit à une déstigmatisation en privilégiant une mixité. ${ }^{2}$ Fondées sur l'assimilation, de telles activités défendent l'universalité de l'humanité et l'unité du genre humain. Depuis le début des années 2000, il bénéficie d'une légitimité politique et sociale sous l'égide de l'inclusion, posée comme une voie pour permettre aux personnes ayant des incapacités de prendre pleinement leur place dans la société.

Traditionnellement, ces deux modalités s'opposent sur le plan idéologique et organisationnel; le loisir adapté et le loisir inclusif restent perçus de manière dichotomique à l'image de deux silos étanches alors qu'il convient de les penser dans une complémentarité tel un continuum qui compose une offre garantissant un plein accès au loisir. Au-delà de la forme de l'activité en tant que telle, il importe de considérer la notion d'expérience inclusive, car elle dépasse cette dichotomie et invite à poser le regard davantage sur le vécu des personnes ayant des incapacités que sur des modalités d'organisation.

Plusieurs auteurs (notamment Pagán, 2015; Powrie et al., 2015) mettent en lumière l'importance de donner accès aux personnes vivant en situation de handicap à des activités signifiantes pour leur permettre de vivre une expérience satisfaisante. Kang et al. (2014) ainsi que Carbonneau et al. (2015) ont identifié trois dimensions qui influencent cette expérience à savoir l'accès physique, le lien social et l'engagement dans une activité. Au-delà de la simple l'intégration à un lieu physique, il est donc crucial d'encourager l'accès à une expérience satisfaisante qui corresponde aux champs d'intérêt et aspirations des personnes. Ainsi, l'expérience inclusive de loisir appelle (1) à donner accès à des lieux et des équipements en lien avec des pratiques signifiantes pour les personnes, (2) à mener à une pratique qui mobilise le potentiel des personnes dans des activités répondant à leurs intérêts et aspirations ainsi qu'à (3) optimiser la possibilité d'entrer en relation de façon significative et réciproque avec les autres participants avec et sans incapacités (Carbonneau et al., 2015). Comme l'illustre la Figure 1, cette expérience inclusive peut prendre diverses formes allant d'une pratique adaptée dans des lieux spécialisés jusqu'à une pratique inclusive en toute liberté.

Il est important de souligner ici qu'il ne s'agit pas d'un continuum où le loisir adapté dans des lieux spécialisés serait la forme la moins intéressante et le loisir inclusif en toute

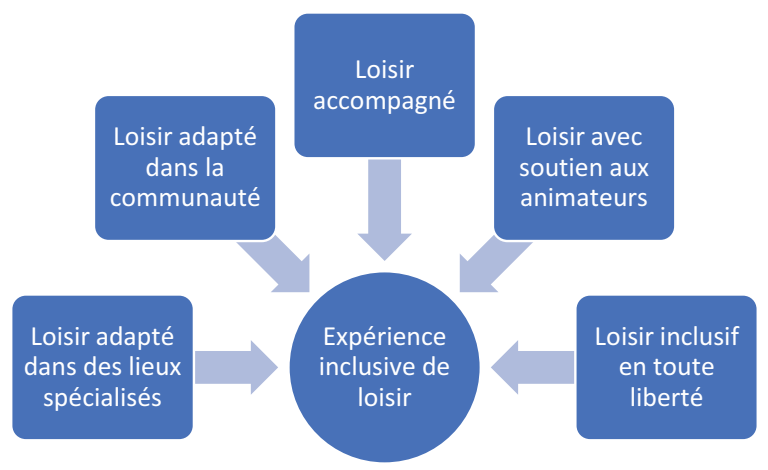

Figure 1. Gamme des possibilités de l'expérience inclusive de loisir (Carbonneau et al., 2015). 
liberté l'apogée de l'expérience de loisir pour une personne ayant des incapacités, mais d'une gamme de possibilités : ce qui importe est que le type de possibilité retenu soit le plus propice à permettre aux participants de réellement vivre une expérience inclusive.

Cette notion d'expérience inclusive rejoint les préoccupations et réflexions de nombreux acteurs du champ du loisir public et de chercheurs du domaine du loisir pour les personnes en situation de handicap. C'est ainsi qu'en octobre 2019, à Trois-Rivières, un premier symposium international sur l'expérience inclusive de loisir réunissait des chercheurs et des intervenants en provenance du Canada, des États-Unis, de la France, de la Suisse, de l'Italie et de l'Espagne. Ce numéro spécial s'inscrit en continuité de ce symposium qui a été riche en échanges autour des tenants et aboutissants du soutien à une expérience inclusive en loisir. Vous y trouverez tant les réflexions de chercheurs marquants dans ce champ que des résultats de recherche dans le domaine.

Pour débuter, l'article de Kenneth Mobily et d'Adrienne Johnson introduit le sentiment d'appartenance au sein de la notion d'expérience. Les auteurs mettent alors l'emphase sur l'expérience d'appartenance et le loisir comme forces majeures pour redéfinir le handicap et sa signification dans la société contemporaine. Le texte d'Anne Marcellini et celui de Mary Ann Devine viennent approfondir le sens et le potentiel de l'inclusion en loisir pour le développement de la société. Marcellini invite à réfléchir aux avenues pour aller au-delà de la co-présence des personnes avec et sans incapacités et mener au développement d'une société inclusive. Devine positionne la notion de loisir inclusif dans une perspective de justice sociale. Elle met en relief que le loisir est davantage qu'une façon d'occuper le temps, mais bien un vecteur majeur de qualité de vie voire de lutte contre l'oppression.

Les deux articles suivants introduisent des modèles conceptuels marquants pour le champ de l'inclusion en loisir dans une perspective écologique. L'article de John Dattilo article présente un modèle d'éducation à l'inclusion considérant l'environnement social et physique. Ce modèle reconnait des stratégies spécifiques pour favoriser l'engagement et l'inclusion. L'objectif de cet article et du modèle lui-même est de former les intervenants dans tous les domaines du loisir à l'inclusion et au développement de services de loisir inclusifs. Un autre modèle d'inclusion est présenté dans l'article de Lynn Anderson. Anderson aborde la pertinence du modèle "Flourishing through leisure " pour mieux saisir comment soutenir des pratiques de loisir inclusives au sein de la communauté. Ce modèle est ancré dans les concepts du modèle social du handicap, de la psychologie positive et de perspective écologique. Puis, l'article de Rodney Dieser vient ajouter une dimension interculturelle à cette analyse. Cet article met en exergue la signification de la théorie de normalisation comme base pour une approche multiculturelle de loisirs inclusifs à partir d'une analyse comparative des écrits de Nirje et de Wolfensberger. Le texte de Darla Fortune approfondit la réflexion en lien avec l'inclusion en loisir au sein de la communauté autour de la notion du développement du sentiment d'appartenance. Fortune développe cinq thèmes mettant de l'avant des moyens d'améliorer l'appartenance, en particulier pour les personnes susceptibles d'être exclues.

L'article de Valérie Poulin et al. ainsi que celui de Marie-Michèle Duquette et collaborateurs mettent de l'avant des exemples en relation avec des recherches portant sur l'expérience inclusive de loisir. L'article suivant proposé par Poulin et ses collègues présente les résultats d'une étude qui a exploré les conditions d'une expérience inclusive de loisir dans des ateliers créatifs au sein de bibliothèques. Cet article illustre qu'une expérience inclusive de loisir se dessine en trois temps soit avant, pendant et après l'activité. Le dernier article consiste en une note de recherche par Duquette et ses 
collègues qui met en lumière certains enjeux pour la réalisation d'une étude autour de la question de l'expérience inclusive. Il montre l'importance d'un ancrage étroit avec le milieu de la pratique dès la conceptualisation du projet, incluant la formation des acteurs, jusqu'à son évaluation pour des retombées optimales de la recherche sur l'inclusion en loisir.

Si les écrits présentés sont surtout centrés sur le cas de l'inclusion en loisir des personnes en situation de handicap, les notions qui y sont développées concernent aussi l'accès d'autres publics à une expérience inclusive de loisir. Nous espérons que la lecture des divers textes contenus dans ce numéro spécial contribuera à une meilleure compréhension de l'inclusion en loisir et de l'importance de dépasser la simple cohabitation de divers publics pour tendre vers le soutien à l'atteinte d'une expérience inclusive pour tous. Bonne lecture.

\section{Notes}

1. Between persons with and without disabilities.

2. Entre personnes avec incapacités et sans incapacités.

\section{Disclosure statement / Déclaration}

No potential conflict of interest was reported by the authors / Aucun conflit d'intérêts potentiel n'a été rapporté par les auteurs.

\section{Références}

Calvez, M. (1990). Les handicapés mentaux et l'intégration ordinaire : une analyse culturelle, Handicap et Inadaptations. Les cahiers du CTNERHI, 51-52, 31-58.

Carbonneau, H., Cantin, R., et St-Onge, M. (2015). Pour une expérience de loisir inclusive. Bulletin de l'Observatoire Québécois du Loisir, 12 (11), 4. Québec.

Kang, L. J., Palisano, R. J., King, G. A., \& Chiarello, L. A. (2014). A multidimensional model of optimal participation of children with physical disabilities. Disability and Rehabilitation, 36 (20), 1735-1741. https://doi.org/10.3109/09638288.2013.863392

Pagán, R. (2015). How do leisure activities impact on life satisfaction? Evidence for German people with disabilities. Applied Research in Quality of Life, 10(4), 557-572. http://dx.doi.org/ 10.1007/s11482-014-9333-3

Powrie, B., Kolehmainen, N., Turpin, M., Ziviani, J., \& Copley, J. (2015). The meaning evidence of leisure for children and young people with physical disabilities: A systematic synthesis. Developmental Medicine \& Child Neurology, 57(11), 993-1010. https://doi.org/10.1111/dmcn. 12788

Pronovost, G. (2017). Traité de sociologie empirique (3ème ed.). Presses de l'Université du Québec.

Reichhart, F. (2005). La cristallisation du lien social des usagers du secteur médico-social. Limits concerning social interactions of people with intellectual deficiency. Revue Francophone de la Déficience Intellectuelle, 16(1-2), 63-73.

Reichhart, F. (2007). Le loisir, reflet de la personne handicapée et indicateur de son degré de socialisation. Loisir et Société/Society and Leisure, 29(2), 505-522. https://doi.org/10.1080/ 07053436.2006.10707729 